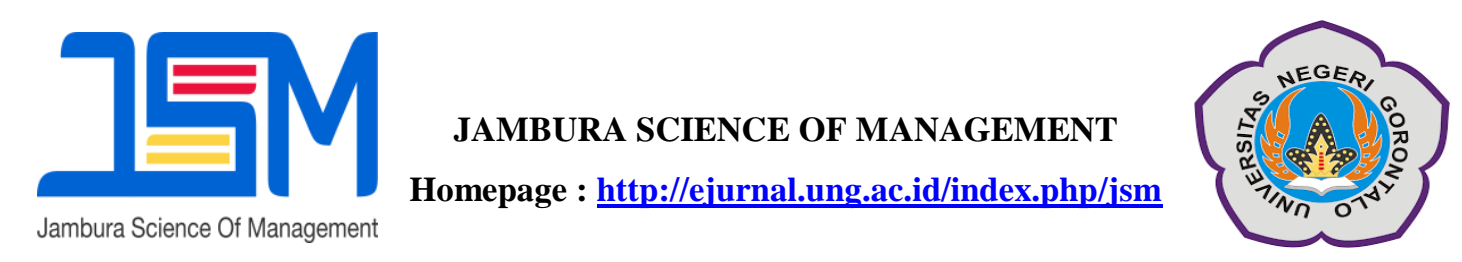

\title{
Organizational Climate Conditions and Work Productivity of State Civil Apparatus Towards the Year of Politics in Gorontalo Province
}

\author{
Agus Hakri Bokingo \\ Department of Management, Faculty of Economics, Gorontalo State University \\ E-Mail : Agushakri@ung.ac.id
}

\begin{abstract}
:
This study aims to obtain an overview of the organizational climate and its influence on the productivity of ASN work in Gorontalo Province. A total of 46 employees from 8 SKPD (Service Unit Work Unit) were made as speakers and were given questionnaires to obtain information regarding their perceptions regarding organizational climate and measuring how high their work productivity was. The researcher revealed that the organizational climate in the Gorontalo Provincial Government so far was quite conducive. However, towards the political year, according to respondents, there were often several maneuvers carried out by SKPD leaders. Likewise, the work productivity of employees is fairly good. It is proven by the annual performance report that shows the performance achievement of employees who meet the target. Improving work productivity is also influenced by organizational climate conditions. The results of the study show that the organizational climate influences the work productivity of the state civil apparatus in Gorontalo Province. Of the many factors that can affect work productivity, $10.3 \%$ of them are influenced by organizational climate factors.
\end{abstract}

\section{Keywords: Organizational Climate, Work Productivity, Year of Politics, ASN.}

Increasing work productivity is only possible for humans. labor is a determinant factor in measuring the work productivity of a company or institution, It can be said that productivity is a comparison between the results of an employee's work and the sacrifices that have been spent. As said by Siagian (2002) that productivity is the ability to obtain the maximum benefit from the available facilities and infrastructure by producing optimal output even if possible the maximum.
The phrase describes the increase in production and increase in productivity which basically becomes the main role is human resources in the process of increasing productivity, because the means of production and technology are essentially the result of human labor. Problems related to productivity are also strategic issues for companies and agencies that program human resource problems. Many internal and external aspects that support the creation of 
effective and efficient work productivity in a company and / or agency. Especially if it is associated with political issues towards 2019 which we feel very much the impact. One indicator that influences efforts to improve productivity effectively and efficiently is the organizational climate applied by an agency.

Organizational structure is basically an organizational design where the leader allocates organizational resources, especially those related to the division of labor with the resources that the organization has, and how the overall work can be coordinated and communicated. According to Stoner, Freeman and Gilbert in Erni and Kurniawan (2005), there are four pillars that form the basis for organizing the process, the four pillars are division of labor, grouping of jobs, determination of relations between parts of the organization, and determination of mechanisms to integrate inter-inner activities organization.

The main problem faced by organizations so that the goals that have been set can be achieved is how the organization can be structured. Organizational climate is a concept that refers to a number of traits that can be measured in a work environment or internal atmosphere within an organization that are felt directly or indirectly by the individuals working in it. The internal atmosphere of the organization is assumed to affect employee productivity. The organizational climate is very important because with a conducive organizational climate, every individual, work team and leader will know, understand and implement work according to their duties, functions, work, position, rights and obligations, communication, and authority and responsibilities.

Davis and Newstrom (2001) view organizational climate as the personality of an organization that differentiates it from other organizations which leads to the perception of each member in looking at the organization. So it can be concluded that the organizational climate is a series of descriptions of organizational characteristics that distinguish an organization from other organizations that lead to the perception of each member in looking at the organization. Employees who work in a government agency are required to be able to complete their duties and responsibilities effectively and efficiently because the performance of their human resources is able to provide positive and beneficial contributions to government agencies (Sari, 2009 in Sarah and Wayan, 2015). The organizational climate will basically create a comfortable working atmosphere. Therefore the division of tasks and responsibilities evenly within a government agency must be evenly distributed so that employees can contribute positively to the completion of effective and efficient work.

Along with the development of the national and international strategies faced today and in the future requires changes in the paradigm of governance, renewal of the institutional system, increasing the competence of human resources in the administration of government and nation- 
building and relations between nations that lead to the implementation of good governance. Thus each executor is required to always excel, especially with daily tasks that become obligations, and arranged in a job description.

In general, each local government agency carries out its duties due to problems with employee productivity. Similarly, experienced by employees in the Gorontalo provincial government. Therefore, it is necessary to further examine the organizational climate indicators that affect the work productivity of employees in government agencies. There are various phenomena that show that work absences often occur, delays in doing tasks, lack of creativity or loss of interest in those who were previously liked, the work environment that is felt less comfortable, and lack of communication between the leader and coworkers.

\section{METHOD}

Descriptive analysis is carried out to explain the characteristics of the variables under study, namely organizational climate conditions and work productivity. Hypothesis testing was also taken to determine the effect of organizational climate on work productivity.

\section{RESULTS AND DISCUSSION}

It is known that the value of $t_{\text {count }} X$ is greater than the value of $t_{\text {table }}$ that is $2.250>1,678$, thus $\mathrm{Ha}$ is accepted and $\mathrm{H} 0$ is rejected. So that the researchers concluded that there is an influence between organizational climate on employee productivity. The significance value $<0.05$ indicates that the influence given by the organizational climate on employee work productivity is significant. The value of $\mathrm{R} 2$ is 0.103 or can be presented to be $10.3 \%$. In other words, the magnitude of the influence given by the organizational climate on employee work productivity is only $10.3 \%$, while the remaining $89.7 \%$ is influenced by other factors such as compensation, level of education owned, and the level of difficulty of workload faced by employees.

\section{Organizational Climate and Work Productivity}

Organizational climate and employee work productivity are the most important things in an organization related to employee behavior in this case work productivity. The results of the analysis prove that the organizational climate has a positive and significant effect on employee work productivity. However, it should also be noted that to stimulate employee work productivity is not enough just to focus on the climate of the organization, but also must pay attention to matters relating to motivation such as providing appropriate compensation, placement of employees in accordance with the employee's background, and distributing the burden work fairly and evenly to all elements of the employee in the office. This is because the factors that affect employee work productivity are not just organizational climates but there are still other factors 
that contribute to increasing employee work productivity.

\section{CONCLUSION}

Conclusions that can be drawn by researcher in this study are organizational climate that influences employee productivity. It is fitting that the agency seeks to maintain and even increase the productivity of its employees. Given that the current organizational climate has not been fully representative of what is desired by employees. The results of the study are in line with the findings of previous researchers, as conducted by Karyana (2012), Pangumpia (2013), and Atik, et al (2016) who also conclude that organizational climate greatly influences the increase in employee productivity both in government agencies and in private organizations.

\section{REFERENCES}

Anoraga, Pandji. 2007. Pengantar Bisnis. Jakarta. Rineka Cipta

Barnes, James. 2003. Secrets Of Costumer Relationship Management. Yogyakarta. Andi Offset

Davis, Keith dan Newstrom, 2001. Perilaku Dalam Organisasi. Edisi Ketujuh. Penerbit Erlangga ; Jakarta

Ernie dan Kurniawan. 2005. Pengantar Manajemen. Jakarta. Prenada Media Group

Ghozali, Imam. 2001. Analisis Multivariate dengan Program SPSS. Semarang. Badan Penerbit Universitas Diponegoro.
Handoko, T Hani. 2000. Manajemen. Edisi 2. Yogyakarta. BPFE

Karyana, Ayi. 2012. Pengaruh Iklim Organisasi Terhadap Produktivitas Kerja Di Unit Pelaksana Teknis Kurikulum Kecamatan Jasinga Kabupaten Bogor. Bogor. Fakultas Sospol Universitas Terbuka

Kusdiana, Atik; Leonardo Budi Hasiolan, dan Azis Fathoni. 2016. Pengaruh Iklim Organisasi, Pengembangan Karir dan Kepuasan Kerja Terhadap Produktifitas KaryawanPT. AST Indonesia Jurnal Manajemen, vol. 2. Semarang: Universitas Pandanaran.

Kusnendi. 2003. Ekonomi Sumber Daya Manusia dan Alam. Jakarta. Universitas Terbuka

Lussier, N Robert, 2005. Human Relations in Organization Applications and skill Building. New York: Mc Graw Hill.

P. Siagian, Sondang.2002. Kepemimpinan Organisasi \& Perilaku Administrasi, Jakarta: Penerbit Gunung Agung Pangumpia, Fadly. 2013. Pengaruh Iklim Komunikasi Organisasi Terhadap Produktivitas Kerja Karyawan Di Bank Prisma Dana Manado. Journal “Acta Diurna”.Vol.II/No.2/2013. Unsrat Manado

Robbins SP, dan Judge. 2007. Perilaku Organisasi. Jakarta. Salemba Empat Sarah dan Wayan. 2015. Pengaruh Iklim Organisasi dan Motivasi Kerja pada kepuasan kerja pegawai balai wilayah Bali-Penida (E-Jurnal 
Manajemen Unud). Bali. Fakultas Ekonomi dan Bisnis Unud

Siagian, S. P. (2002). Kiat Meningkatkan

Produktivitas Kerja. Jakarta. Rineka cipta

Simamora, Henry. 2004. Manajemen Sumber Daya Manusia. Edisi Ke-3. STIE YKPN. Yogyakarta

Sinungan, Muchdarsyah. 2005.

Produktivitas : Apa dan Bagaimana.

Edisi Kedua. Bumi Aksara.

Sugiyono. 2011. Metode Penelitian

Kuantitatif Kualitatif Dan $R \& D$.

Bandung. Alfabeta

Sumantri, Suryana. 2001. Perilaku Organisasi. Bandung. Universitas Padjadjaran.
Sumarni dan Wahyuni. 2006. Metodologi Penelitian Bisnis. Yogyakarta. Andi Offset

Suryana Sumantri (2001). Perilaku Organisasi. Bandung: Universitas Padjadjaran.

Sutrisno, Edi. 2009. Manajemen Sumber Daya Manusia Edisi pertama. Jakarta: Kencana Prenada Media Group

Umar, Husein. 2003. Metodologi Penelitian, Aplikasi dalam Pemasaran. Jakarta. Gramedia Pustaka Utama.

Wirawan. 2008. Budaya dan Iklim Organisasi. Jakarta. Salemba Empat. 